\title{
PERILAKU ADAPTASI DAN PERUBAHAN PENATAAN HUNIAN DI MASA PANDEMI COVID-19
}

\author{
Imaniar Sofia Asharhani*), Marchelia Gupita Sari \\ *) Corresponding author email :imaniar.sofia@ pradita.ac.id \\ Program Studi Arsitektur, Universitas Pradita
}

\begin{tabular}{l} 
Article info \\
MODUL vol 21 no 2, issues period 2021 \\
\hline Doi $\quad: 10.14710 /$ mdl.21.2.2021.102-110 \\
Received $: 17$ mei 2021 \\
Revised $: 18$ agustus 2021 \\
Accepted $: 27$ agustus 2021
\end{tabular}

\section{Abstrak}

Penyesuaian perilaku selama Pandemi Covid-19 akibat perubahan pola kegiatan bekerja dan belajar dari rumah memberikan dampak besar pada kegiatan seharihari di dalam rumah. Penelitian ini bertujuan untuk mengungkap faktor yang mempengaruhi tingkat kepuasan penghuni dan mengungkap ragam modifikasi hunian yang dilakukan selama masa Pandemi Covid-19. Hasil penelitian diharapkan dapat digunakan untuk menjadi rekomendasi desain untuk hunian yang adaptif apabila terjadi perubahan situasi yang tiba-tiba. Penelitian ini menggunakan metode penelitian kualitatif untuk mengetahui kecenderungan kepuasan penghuni pada proses penataan ulang dalam rumah tinggal. Sampel data dikhususkan kepada keluarga yang melaksanakan bekerja dan belajar dari rumah pada masa protokol menjaga jarak ditetapkan. Pengambilan data ditujukan kepada sejumlah narasumber dan dilakukan wawancara mengenai kepuasan mereka terhadap perubahan yang terjadi pada hunian masingmasing. Narasumber tersebut sekaligus berlaku menjadi pengamat perubahan yang terjadi di hunian mereka. Analisis mengenai ragam perubahan dilakukan dengan membuat klasifikasi terhadap jumlah dan jenis perubahan yang dilakukan. Hasil penelitian menunjukkan bahwa tingkat kepuasan penghuni memiliki kecenderungan kearah positif dengan adanya kompromi terhadap fungsi beragam dalam satu ruangan dan terjadi peningkatan perawatan ruangan, serta kompromi terhadap kebisingan. Tipe perubahan yang paling banyak ditemukan adalah pembagian dan penukaran fungsi ruangan.

Imaniar Sofia Asharhani, Marchelia Gupita Sari
Keywords: telework; adaptasi; modifikasi; penataan; hunian; covid-19

\section{PENDAHULUAN}

Kejadian luar biasa di dunia pada awal tahun 2020 lalu, akibat mewabahnya virus Covid-19, membuat berbagai negara kemudian mulai menerapkan Protokol Kesehatan sesuai dengan anjuran World Health Organization (WHO). Anjuran yang diberlakukan antara lain cuci tangan, tidak berkumpul/melakukan pertemuan, menjaga jarak, membatasi keluar rumah bahkan dilakukan langkah isolasi mandiri, pembatasan sosial, hingga pemberlakuan karantina pada suatu daerah maupun negara. Dampak dari berbagai anjuran tersebut mengakibatkan sekolah, pendidikan tinggi, dan kantor pemerintah maupun swasta yang kemudian menerapkan skema belajar dan bekerja dari rumah Pembelajaran Jarak Jauh (PJJ) dan Work from Home(WFH). Kegiatan PJJ dan WFH tersebut merupakan bagian dari konsep telecommuting. Istilah telecommuting atau telework, merupakan keadaan para pekerja diberi kesempatan untuk menyelesaikan tugas dari rumah dibandingkan dengan datang langsung ke kantor (Potter, 2003) (Budhiekusuma, 2017). Kegiatan telework terdiri atas praktek kerja leluasa yaitu flexible work; dan lokasi leluasa yaitu flexible place (Grobler dan De Bruyn, 2011); serta waktu leluasa atau flexible time (Munsch et al., 2014; Mungkasa, 2020).

Pada masa pandemi Covid-19, kegiatan telework tersebut merupakan kondisi yang tidak direncanakan dan tiba-tiba, sehingga mengubah perilaku manusia dalam waktu singkat. Terhitung pada survei nasional bahwa 80\% masyarakat Indonesia banyak menghabiskan waktu di rumah selama Pembatasan Social Berskala Besar (Panolih, 2020). Melihat hal tersebut maka akan terjadi adaptasi perilaku dan penyesuaian kondisi lingkungan secara serentak. Adaptasi adalah cara kita mengubah perilaku kita agar sesuai dengan tuntutan lingkungan, sedangkan penyesuaian atau adjustment adalah cara kita 
mengubah atau memodifikasi lingkungan agar sesuai dengan perilaku kita (Indriyati, 2010; Bell \& Fisher 2006). Perilaku adaptasi tersebut dapat dikatakan berhasil atau memuaskan, tergantung dari persepsi setiap pelakunya. Persepsi terjadi saat sejumlah sensasi disatukan melalui proses mediasi dalam struktur sistem saraf otak sehingga kita mengenali atau mengatur pola dari sejumlah sensasi yang telah terakumulasi dalam memori jangka panjang (Bell \& Fisher 2006). Penentuan fungsi yang kompatibel pada ruangan tertentu, apabila kondisi fisik hunian mampu memfasilitasi penataan fungsional tersebut, maka kita cenderung puas dengannya (Bell \& Fisher 2006).

Meskipun tindakan penyesuaian penataan telah dilakukan, ada kalanya kondisi fisik hunian belum mampu memfasilitasi aspek fungsional. Hal tersebut akan memunculkan respon tertentu oleh penghuni. Budaya dapat berubah seiring dengan perubahan lingkung bangun (Rapoport dan Hardie, 1991; Rahim \& Hashim, 2018). Ujaran ini relevan ketika lingkung bangun diperuntukkan sekelompok orang yang homogen yang memiliki kendali atas perubahan yang terjadi. Namun saran tersebut tidak berlaku ketika terjadi perubahan situasi pada lingkungan diluar kendali manusia. Peristiwa perubahan yang terjadi secara tibatiba akan berdampak pada kenyamanan oleh seluruh anggota keluarga. Respon perilaku positif yang digunakan keluarga untuk memecahkan suatu masalah atau mengurangi stres yang diakibatkan oleh suatu peristiwa tertentu adalah strategi adaptasi yang disebut strategi coping.

Metode adaptasi coping adalah mengubah atau merancang lingkungan agar lebih sesuai dengan kebutuhan dan perilaku manusia (Bell \& Fisher 2006; Indriyati 2010). Strategi coping bertujuan untuk mengatasi situasi dan tuntutan yang dirasa menekan, menantang, membebani dan melebihi kemampuan yang dimiliki (Maryam, 2017). Mekanisme coping yang berpusat kepada masalah, salah satunya ialah dengan cara kompromi yaitu mengubah keadaan secara hati-hati, meminta bantuan kepada keluarga dekat dan teman sebaya atau bekerja sama dengan mereka (Stuart dan Sundeen, 1991; Maryam, 2017). Strategi coping yang baik diperlukan kegiatan adaptasi perilaku dan penyesuaian (adjustment) kondisi fisik bagi penghuni rumah (Bell \& Fisher, 2006; Indriyati, 2010). Penjelasan lebih lanjut antara lain: Adaption adalah usaha seseorang sebagai tanggapan atas penyesuaian kondisi fisik pada rumahnya dengan cara melakukan perubahan perilaku. Sedangkan Adjusment yaitu usaha seseorang memenuhi kebutuhan dengan bentuk tindakan berupa membuat perubahan atau penambahan (mengorganisasi ulang) terhadap rumahnya.

Transformasi fisik pada bangunan seringkali terdapat kegiatan penambahan dengan perluasan (expansion), Penyusutan dengan pengurangan (contraction) atau pembagian dengan penyekatan (subdivition) dalam suatu bangunan (Habraken, 2014). Transformasi terjadi dalam kurun waktu yang lama, sedangkan pada situasi khusus, transformasi berupa penyesuaian dapat dilakukan dengan melakukan perubahan. Penelitian sebelumnya telah dilaksanakan untuk mengamati ragam penyesuaian hunian. Salah satunya ialah mengenai perubahan tipe rumah deret masal (Omar, 2017), terdapat enam jenis kemungkinan perubahan fungsi ruang, yaitu dengen perluasan (extension) dan penambahan lantai (addition), pengurangan luasan (reduction) dan penyekatan (division), serta penghilangan (removal) dan perpindahan fungsi (relocation). Perubahan berupa perluasan ialah yang paling diinginkan untuk memperoleh kenyamanan, apabila memungkinkan. Pengurangan ukuran maupun penyekatan dilakukan untuk menyesuaikan kebutuhan yang berubah bagi penghuni rumah. Sementara perpindahan atau relokasi terhadap beberapa fungsi muncul untuk optimalisasi dalam perubahan tanpa mempengaruhi aspek keterbangunan fisik rumah tinggal. Penelitian lain untuk rumah deret masal (Rahim \& Hashim, 2018) ditemukan bahwa hasil modifikasi memeberikan hasil positif berupa pemenuhan kebutuhan ruang, namun konsekuensinya berkurangnya privasi dan minim pencahayaan alami.

Selain pengelompokan tipe perubahan tersebut, terdapat tipe perubahan penataan ruang fleksibel sebagai adaptasi ruang menggantikan keberadaan hirarki ruang. Perubahan penataan terjadi di waktu siang dan malam hari, berdasarkan kebutuhan penghuni seperti: membuka partisi, melipat kasur, untuk area keluarga. Perubahan atau pengaturan ulang dapat dilakukan oleh penghuni seiring dengan berubahnya kebutuhan dan mengakibatkan ruang fleksibel pada rumah tinggal (Raviz et al, 2015). Ruang fleksibel menciptakan keragaman, dinamisme dan kemampuan beradaptasi yang sangat baik untuk memenuhi kebutuhan seluruh anggota keluarga yang beragam (Raviz et al, 2015). Ruang-ruang yang berurutan dan saling terkait menciptakan ruang baru dengan berbagai jenis hubungan spasial. Contohnya area dapur dapat difungsikan menjadi perluasan ruang kerluarga dan ruang makan.

Penelitian terdahulu mengenai adaptasi dan penyesuaian berupa modifikasi hunian, mengungkap perubahan yang terjadi dalam jangka waktu yang lama. Urgensi dari penelitian yang dilakukan ini ialah tipe perubahan terjadi secara mendadak dan terlaksana dalam waktu singkat. Sehingga hasil penelitian ini diharapkan dapat memberi kontribusi kepada penyedia hunian untuk menawarkan hunian yang adaptif dengan kemudahan penataan sesuai perubahan kebutuhan, khususnya untuk 
kegiatan telework. Pada penelitian ini akan dilihat bagaimana tingkat kepuasan penghuni setelah melaksanakan penataan hunian mereka. Kemudian akan mengungkap seperti apa kegiatan kompromi atau adaptasi coping terhadap situasi perubahan tersebut. Terakhir, penelitian ini mengungkap bagaimana cara mengubah penataan hunian yang ditinggali oleh anggota keluarga dengan tuntutan kegiatan telework baik pelajar maupun pekerja.

\section{METODE PENELITIAN}

Penelitian ini merupakan penelitian yang bersifat rapid assessment, sehingga menggunakan metode yang lebih menekankan kemudahan pelaksaan penelitian serta efisiensi dalam pencapaian tujuan penelitian. Pemilihan sampel narasumber memakai judgemental atau purposive sampling, bertujuan agar narasumber dapat memberikan informasi terbaik untuk mencapai tujuan penelitian (Kumar, 2005). Oleh karena itu, narasumber merupakan mahasiswa Program Studi Arsitektur Pradita yang memiliki anggota keluarga melaksanakan telework, serta memiliki pemahaman keruangan dan mampu mengkomunikasikan dalam bentuk gambar denah rumah. Kemudian narasumber tersebut juga menjadi pengamat perubahan penataan pada hunian mereka masing-masing. Jenis penelitian ini merupakan penelitian deskriptif kualitatif yang kemudian dikuantitatifkan. Hal ini bertujuan untuk mempermudah dalam memperoleh hasil penelitian. Pada Gambar 1 memperlihatkan alur penelitian ini dilakukan.

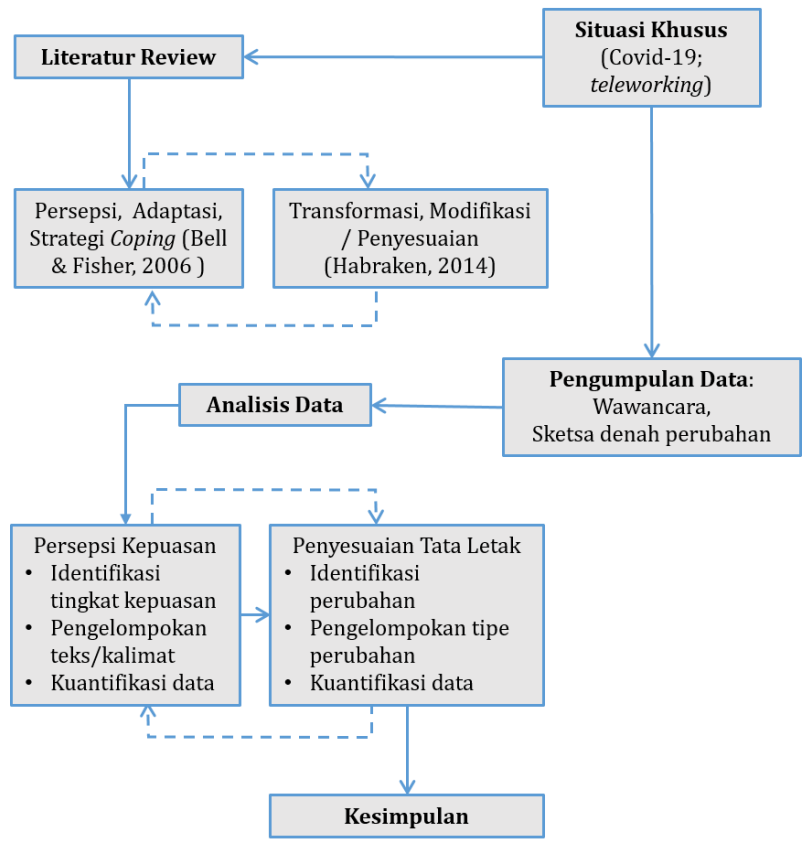

Gambar 1. Diagram Alur Penelitian

\section{HASIL DAN PEMBAHASAN \\ Persepsi Tingkat Kepuasan}

Persepsi menjadi sebuah bagian proses mental dimana diri kita berkaitan dengan lingkungan sekitar, yang kita alami dan upayakan untuk mendapatkan kepuasan (Ittelson, 1969; Indriyati, 2010). Adaptasi perilaku terhadap perubahan tata atur dengan segala keterbatasannya memberikan persepsi kepuasan yang beragam (Indriyati, 2010). Upaya untuk beradaptasi dengan lingkungannya terjadi pada kondisi Pandemi Covid-19 bagi para penghuni rumah. Pengalaman berhuni dan melakukan aktivitas belajar dan bekerja dengan tata atur yang berbeda membuat penghuni merasakan perubahan. Misalnya sebelum diterapkan protokol jaga jarak sosaial, kegiatan belajar dan bekerja dilaksanakan di luar rumah, pada situasi pandemi kegiatan tersebut dilaksanakan di dalam rumah. Selain itu, kondisi rumah sebelumnya dihuni oleh anggota keluarga lebih sedikit, saat ini anggota keluarga bertambah karena himbauan telework berupa PJJ dan WFH.

Pada penelitian ini terdapat 20 narasumber, yang memiliki lebih dari 1 ruangan untuk difungsikan menjadi area belajar maupun bekerja. Total ruangan yang dinilai mencapai 40 ruangan yang dinilai oleh 20 narasumber ini. Penelitian mengarahkan adanya respon kepuasan positif maupun negatif terhadap area belajar dan bekerja selama masa telework. Skala diferensial semantik (semantic differential scale) dari Osgood yang merupakan pasangan dua kutub (bipolar) kata-kata sifat pada suatu kontinum favorabel ke tidak favorabel (Gaguk, 2014). Skala semantik digunakan pada penelitian yang pernah dilakukan terdahulu untuk menunjukkan persepsi penghuni. Skala 1 sampai 5 berarti meningkat dari respon negatif ke respon positif. Rerata 3,00 di atas yang diperoleh dikategorikan untuk respon positif dan di bawahnya dikategorikan untuk respon negatif (Indriyati, 2010).

Pada penelitian ini, narasumber diminta memberikan penilaian dengan rentang skala untuk memberikan penilaian tentang kepuasan terhadap penataan hunian di masa Pandemi Covid-19. Kutub respon tidak puas ada di angka 1 dan kutub respon puas ada di angka 5. Berdasarkan wawancara kepada 20 narasumber mengenai penjelasan tentang kepuasan mereka terhadap adanya kondisi ruang, dilakukan pendataan terhadap ragam kalimat pernyataan. Pernyataan tersebut adalah alasan yang muncul atas tingkat kepuasan untuk masing-masing aktivitas terkait bekerja dari rumah dan pembelajaran jarak jauh, serta aktivitas sehari-hari lainnya di rumah.

Kemudian untuk memudahkan analisis mengenai tingkat kepuasan, langkah selanjutnya yang dilakukan adalah mengelompokan setiap jawaban yang muncul dari narasumber, sesuai dengan kesamaannya. Hal ini 
dilakukan dengan memberikan frase atau kalimat yang dapat mewakili beberapa kalimat pernyataan. Tahap ini menggunakan intepretasi tim peneliti dan diskusi internal agar frasa atau kalimat yang diberikan menjadi seideal mungkin supaya tidak memunculkan perbedaan pemahaman. Frasa atau kalimat inilah yang dianggap sebagai faktor-faktor yang mempengaruhi mengenai persepsi tingkat kepuasan penghuni terhadap perubahan penataan hunian (Tabel 1). Persepsi mengenai kepuasan terhadap kondisi hunian di masa Pandemi ditemukan beberapa faktor pengaruh, antara lain adalah: Penerangan dan penghawaan; Kondisi sama seperti sebelumnya (tidak banyak perubahan); Luas ruangan; Kesesuaian penataan dengan kegiatan; Jaringan internet; Terdapat alternatif ruangan; Gangguan Kebisingan; Perawatan ruangan; Privasi suatu kegiatan; Ragam aktivitas dalam satu ruangan.

Hasil pengelompokkan menunjukkan bahwa terdapat pernyataan yang bersifat positif, negatif dan bersifat positif dengan kompromi. Narasumber yang memberikan penilaian kearah puas, namun menjelaskan bahwa penilaian tersebut adalah hasil toleransi terhadap ketidakpuasan yang dialami, maka digolongkan menjadi persepsi positif dengan kompromi.

Sebagai contoh, terdapat 3 kalimat jawaban mengenai perubahan yang terjadi pada beberapa narasumber, yaitu Menghilangkan furnitur tidak terpakai sehingga lebih luas; Terjaga privasi karena terpisah dengan ruang lain, dan sudah diatur untuk mendukung PJJ; Perubahan ruangan menjadi sesuai kebutuhan (studio foto). Kalimat jawaban pernyataan tersebut dikelompokkan dan diwakili oleh kalimat "Penataan ruang diubah sesuai kebutuhan" sebagai kalimat nomor 4 pada Tabel 1 . Contoh lainnya kalimat pernyataan dari narasumber yang diwakili kalimat "Toleransi berbagi fungsi lain dalam satu ruangan" pada nomor 8 antara lain: Menjadi ruang multifungsi (penambahan area belajar dan kerja); Cukup baik, namun tempat sempit; Mengurangi area belajar dan kurang ergonomis karena berbagi tetapi masih cukup.

Berdasarkan data tertampil, pada Tabel.1 mengenai faktor pengaruh terhadap persepsi tingkat kepuasan, memperlihatkan bahwa persentase untuk kepuasan yang memiliki kecenderungan positif ialah sebesar 59\%, kecenderungan negatif adalah $28 \%$ dan kecenderungan kompromi adalah 13\%. Dari data tertampil, adaptasi yang dilakukan memberi persepsi kearah positif dengan alasan karena kondisi ruang sama seperti sebelumnya, Ruangan lebih luas, Penataan diubah sesuai kebutuhan, Penerangan dan penghawaan alami, Ruangan bersifat fleksibel.

Terdapat pula persepsi positif dengan kompromi. Antara lain: Toleransi berbagi fungsi lain dalam satu ruangan; Toleransi gangguan kebisingan; Toleransi peningkatan perawatan ruang; dan Toleransi kegiatan memerlukan jaringan (internet). Beragam toleransi ini muncul sebagai sebuah adaptasi coping yang berpusat pada masalah. Karena keterbatasan ruang yang kurang mendukung fungsi, maka antar anggota keluarga melakukan kompromi melakukan kegiatan bekerja dan belajar di rumah bersamaan sehingga anggota keluarga beradaptasi dengan kebisingan. Anggota keluarga juga mentolerasi dalam satu ruangan dapat dilaksanakan lebih dari 1 kegiatan, baik dilaksanakan bersamaan maupun bergantian, seperti misalnya istirahat dan bekerja/belajar, kegiatan makan dan bekerja/belajar, serta menerima tamu bergantian dengan belajar/bekerja.

Kompromi selanjutnya ialah meningkatnya perawatan ruangan. Misalnya ruang dapur, kamar tidur, dan kamar mandi, seringkali perlu dibersihkan, karena bertambahnya jumlah anggota keluarga yang berada di rumah dan intensitas penggunaan menjadi meningkat. Hal lain yang dilakukan adaptasi adalah toleransi melaksanakan kegiatan dalam jaringan (internet), mengakibatkan pengkondisian jaringan internet perlu menjangkau ruang-ruang untuk kegiatan telework. Atau sebaliknya, ruang-ruang perlu disesuaikan dengan area jangkauan jaringan internet.

Tabel 1. Faktor Pengaruh Terhadap Persepsi Tingkat Kepuasan Penghuni terhadap Perubahan Penataan Hunian

\begin{tabular}{|c|c|c|}
\hline No. & Faktor Pengaruh & Persentase \\
\hline & Persepsi positif & \\
\hline 1 & $\begin{array}{l}\text { Penerangan \& penghawaan alami } \\
\text { yang baik }\end{array}$ & 0.053 \\
\hline 2 & $\begin{array}{l}\text { Kondisi sama atau tidak banyak } \\
\text { perubahan }\end{array}$ & 0,310 \\
\hline 3 & Ruangan terasa lebih luas & 0,090 \\
\hline 4 & $\begin{array}{l}\text { Penataan ruang diubah sesuai } \\
\text { kebutuhan }\end{array}$ & 0,075 \\
\hline 5 & Jaringan internet baik & 0,007 \\
\hline 6 & $\begin{array}{l}\text { Pilihan alternatif ruang sesuai } \\
\text { keinginan }\end{array}$ & 0,030 \\
\hline \multirow[t]{2}{*}{7} & Ruangan bersifat fleksibel & 0,022 \\
\hline & Persepsi Positif dengan Kompromi & \\
\hline 8 & $\begin{array}{l}\text { Toleransi berbagi fungsi lain } \\
\text { dalam satu ruangan }\end{array}$ & 0,068 \\
\hline 9 & Toleransi gangguan kebisingan & 0,008 \\
\hline 10 & $\begin{array}{l}\text { Toleransi peningkatan perawatan } \\
\text { ruang }\end{array}$ & 0,015 \\
\hline 11 & $\begin{array}{l}\text { Toleransi kegiatan memerlukan } \\
\text { jaringan } \\
\text { Persepsi negatif }\end{array}$ & 0,038 \\
\hline 12 & $\begin{array}{l}\text { Ruangan sempit dan/atau tidak } \\
\text { ergonomis }\end{array}$ & 0,114 \\
\hline
\end{tabular}




\begin{tabular}{rlr}
13 & Terdapat gangguan kebisingan & 0,023 \\
14 & Jaringan Internet buruk & 0,008 \\
15 & Berkurang privasi & 0,030 \\
16 & $\begin{array}{l}\text { Penerangan \& penghawaan alami } \\
\text { yang buruk }\end{array}$ & 0,023 \\
17 & $\begin{array}{l}\text { Terganggu oleh aktivitas lain } \\
\text { dalam satu ruangan }\end{array}$ & 0,015 \\
18 & $\begin{array}{l}\text { Ruangan tidak memadai seluruh } \\
\text { aktivitas }\end{array}$ & 0,038 \\
19 & $\begin{array}{l}\text { Belum melakukan penataan } \\
\text { dengan maksimal }\end{array}$ & 0,030 \\
\hline
\end{tabular}

\section{Klasifikasi Penyesuaian Penataan Hunian}

Berdasarkan penelitian sebelumnya, terdapat beberapa tipe perubahan yang tejadi melalui proses yang lama dan bersifat permanen. Latar belakang perubahan yang terjadi adalah akibat dari keinginan memperoleh pembagian area privasi, berubahnya jumlah anggota keluarga, beragamnya gaya hidup anggota keluarga. Gambar 2 mengilustrasikan diagram perubahan yang mungkin terjadi, berdasarkan beberapa penelitian terdahulu, yang juga dilakukan oleh sejumlah narasumber pada penelitian ini, yaitu tipe perluasan, pembagian, penukaran dan fleksibel.

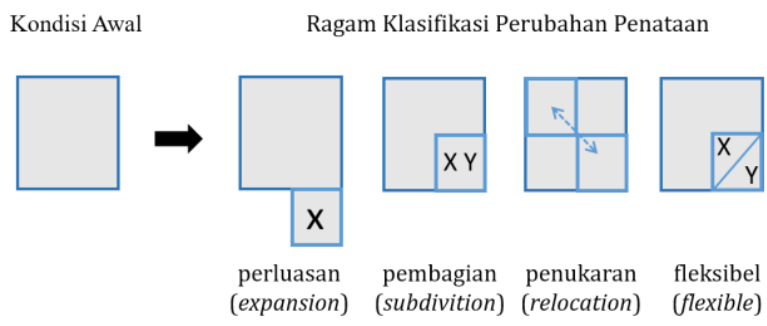

Gambar 2. Diagram Tipe Perubahan Penataan pada Hunian

Perubahan tipe perluasan, seperti penambahan area keluarga dan kamar tamu secara tidak langsung merubah hirarki ruang publik dan privat demi memberikan ruang yang nyaman bagi keluarga untuk beraktivitas (Rahim \& Hashim, 2018). Perubahan berupa penukaran fungsi tertentu terjadi pada pengoptimalan fungsi terkait dalam proses perubahan yang tidak mempengaruhi luas bangunan (Omar, 2017). Pengurangan ukuran ruang melalui pembagian atau penghapusan ruang dilakukan untuk melakukan penyesuaian terhadap kebutuhan fungsional individu (Omar, 2017). Pada penataan fleksibel, jika jumlah anggota rumah bertambah, maka tata letak hunian akan memiliki kemungkinan untuk diubah ke tata letak yang baru (Raviz et al, 2015). Dan proses penggunaan malam hari dan siang hari, akan disesuaikan dengan berbagai gaya hidup anggota keluarga, untuk penataan hunian fleksibel.

Perubahan yang dilakukan oleh setiap keluarga akan dilihat apakah terjadi pada setiap hunian melalui pendataan tata letak hunian 20 narasumber, sebelum dan selama Pandemi Covid-19. Penyesuaian penataan hunian yang dilakukan narasumber, diduga akan bersifat sementara dan sebagai respon cepar dari perubahan yang tiba-tiba. Untuk melihat penataan yang dilakukan oleh narasumber yang melaksanakan belajar dan bekerja dari rumah, serta melakukan kegiatan produksi di rumah, maka terlebih dahulu dilakukan identifikasi terhadap tipe-tipe perubahan penataan rumah mereka melalui bantuan setiap narasumber untuk menggambarkan perubahan yang terjadi. Dalam rangka memudahkan penelitian, narasumber diberi arahan untuk memfokuskan informasi fungsi ruang menggunakan simbol furnitur yang mengindikasikan posisi suatu kegiatan dilakukan.
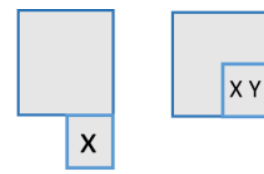

1. Perluasan

2. Pembagian
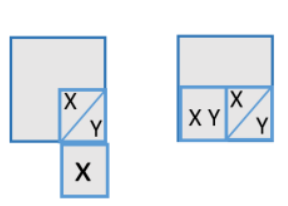
6. Perluasan +
Fleksibel

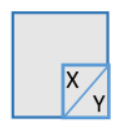

3. Fleksibel

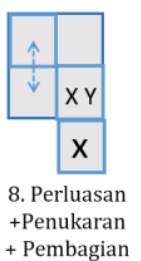

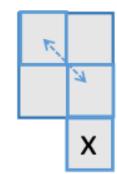

4. Perluasan 5. Penukaran + Penukaran + Pembagian

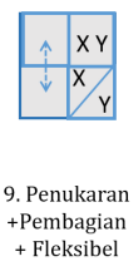

Gambar 3. Diagram 9 Klasifikasi Tipe Perubahan Penataan pada Hunian

Berdasarkan hasil observasi yang dilakukan oleh narasumber sendiri dan kuesioner terstruktur, teridentifikasi bahwa terdapat beberapa tipe perubahan penataan rumah berdasarkan kemunculan kegiatan baru yaitu belajar dan bekerja dari rumah. Pada 20 narasumber ada yang melakukan satu jenis perubahan, dua jenis perubahan, dan tiga jenis perubahan, dengan total ada sembilan jenis tipe konfigurasi perubahan, seperti yang ditunjukkan pada Gambar 3. Pada kategori hunian yang melakukan satu jenis perubahan, didapatkan tipe perubahan berupa (1)perluasan, (2)pembagian, dan (3)fleksibel. Kemudian untuk kategori dua jenis perubahan terdapat tipe (4)perluasan dan pertukaran; (5)pembagian dan pertukaran; (6)perluasan dan fleksibel; serta (7)pembagian dan fleksibel. Terakhir untuk kategori tiga jenis perubahan terdapat tipe (8)perluasan, pertukaran dan pembagian; dan (9)pertukaran, pembagian, dan fleksibel. 


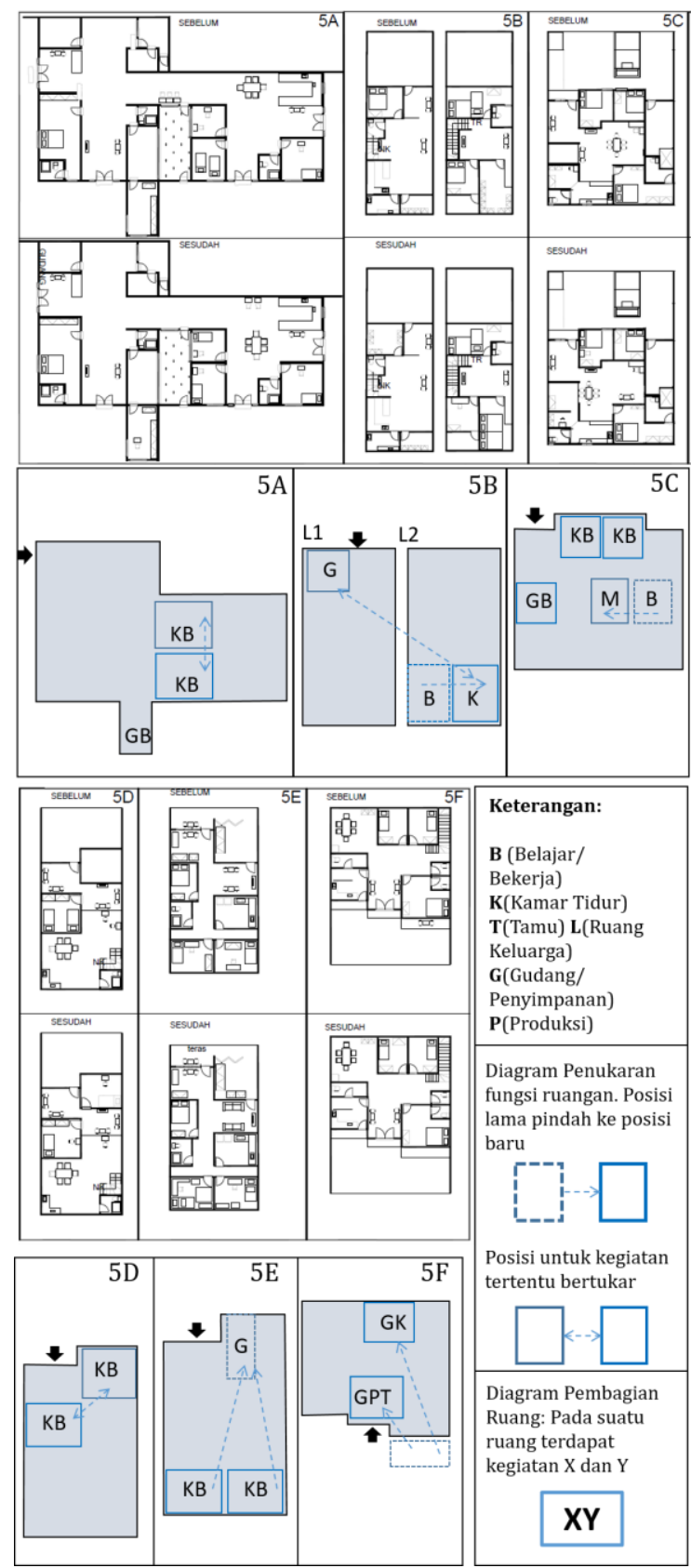

Gambar 4. Proses Analisis pada Klasifikasi Perubahan Penataan berupa Penukaran \& Pembagian

Kategori dua perubahan yaitu klasifikasi tipe penukaran dan pembagian, paling banyak ditemui diantara 20 narasumber, yaitu terdapat 6 rumah yang melakukan perubahan demikian, tertampil pada Gambar 4. Tujuan dari narasumber melakukan perubahan tersebut adalah untuk memaksimalkan efektifitas ruangan yang tersedia untuk melakukan kegiatan bekerja dan belajar dari rumah, serta memaksimalkan ruang penyimpanan atau gudang di dalam rumah sekaligus sebagai ruang produksi. Berdasarkan pada Gambar 6, Penukaran terjadi pada rumah 5A dan 5D untuk memperoleh kondisi kamar yang terdapat area tidur dan belajar, karena sebelumnya ruang tidur terpisah dengan ruang belajar. Pada rumah 5B penukaran dilakukan agar satu ruangan dapat digunakan sebagai kamar tidur anggota keluarga, dan pembagian dilakukan agar memperoleh ruang bekerja tambahan. Penukaran pada rumah 5C dan 5E dimaksudkan agar memperoleh ruang bekerja yang lebih luas, untuk rumah $5 \mathrm{E}$ area gudang/penyimpanan disatukan pada suatu ruang. Rumah 5F melakukan penukaran sehingga ruang produksi dan area gudang penyimpanan ada di dalam rumah, serta pembagian ruang untuk memaksimalkan gudang penyimpanan di beberapa ruang. Adanya kegiatan produksi seperti membungkus produk jualan online, dan inventarisir produk tersebut di dalam rumah merupakan kegiatan baru yang terjadi pada rumah $5 \mathrm{~F}$.

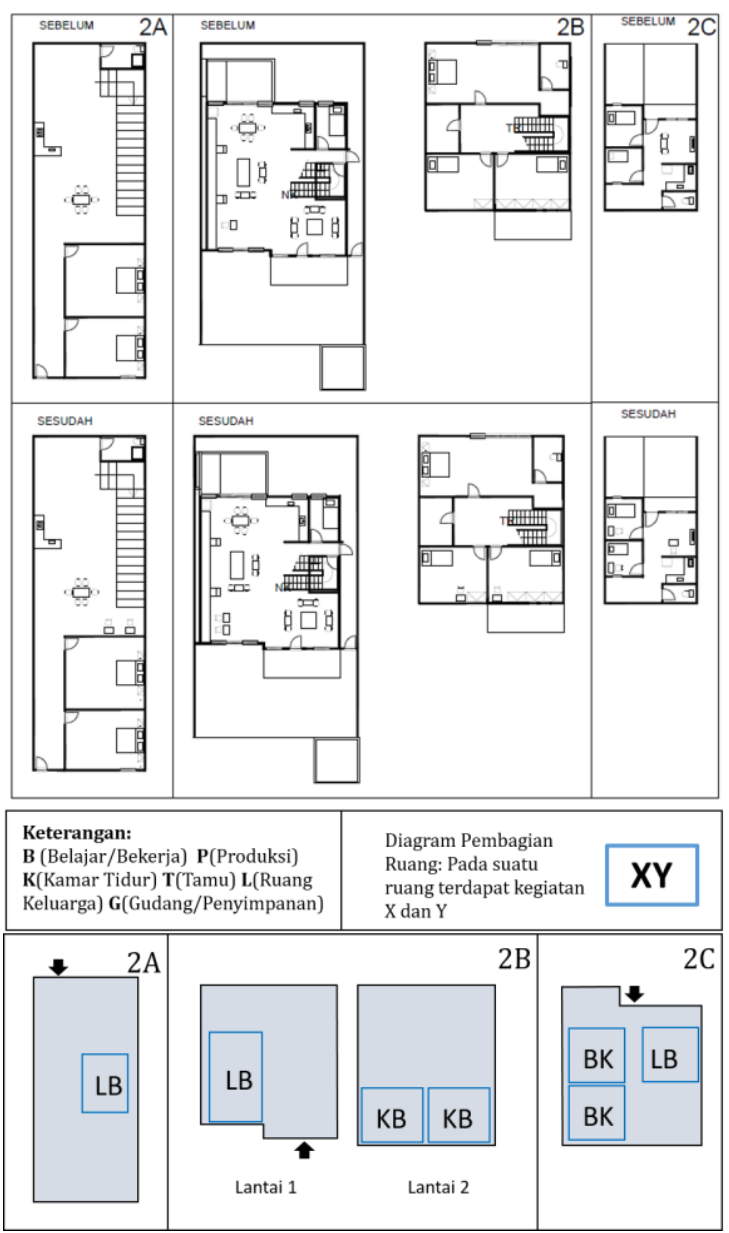

Gambar 5. Proses Analisis pada Klasifikasi Perubahan Penataan berupa Pembagian (Penulis, 2020)

Kategori 2 perubahan dengan klasifikasi pembagian dan fleksibel juga dilakukan oleh 3 
narasumber. Pembagian yang dilakukan bertujuan agar setiap anggota keluarga dapat melakukan belajar atau bekerja di ruangan yang terpisah. Tetapi karena adanya area yang jarang digunakan seperti meja makan dan ruang tamu, maka kegiatan bekerja dan belajar dilakukan bergantian dengan kegiatan makan, serta jika tidak ada tamu, ruang tamu digunakan untuk belajar. Berdasarkan Gambar 6, pembagian dilakukan pada rumah 7A, 7B, dan 7C pada kamar untuk kegiatan belajar dan tidur, supaya tercipta ruang belajar individual. Pada rumah 7B pembagian kegiatan belajar dan santai keluarga terbagi pada ruang keluarga. Fleksibilitas ruang untuk belajar/bekerja terjadi pada rumah 7A dan 7B pada area makan dan tamu jika tidak sedang digunakan. Pada rumah $7 \mathrm{C}$ kegiatan produksi dilakukan bergantian dengan kegiatan makan.

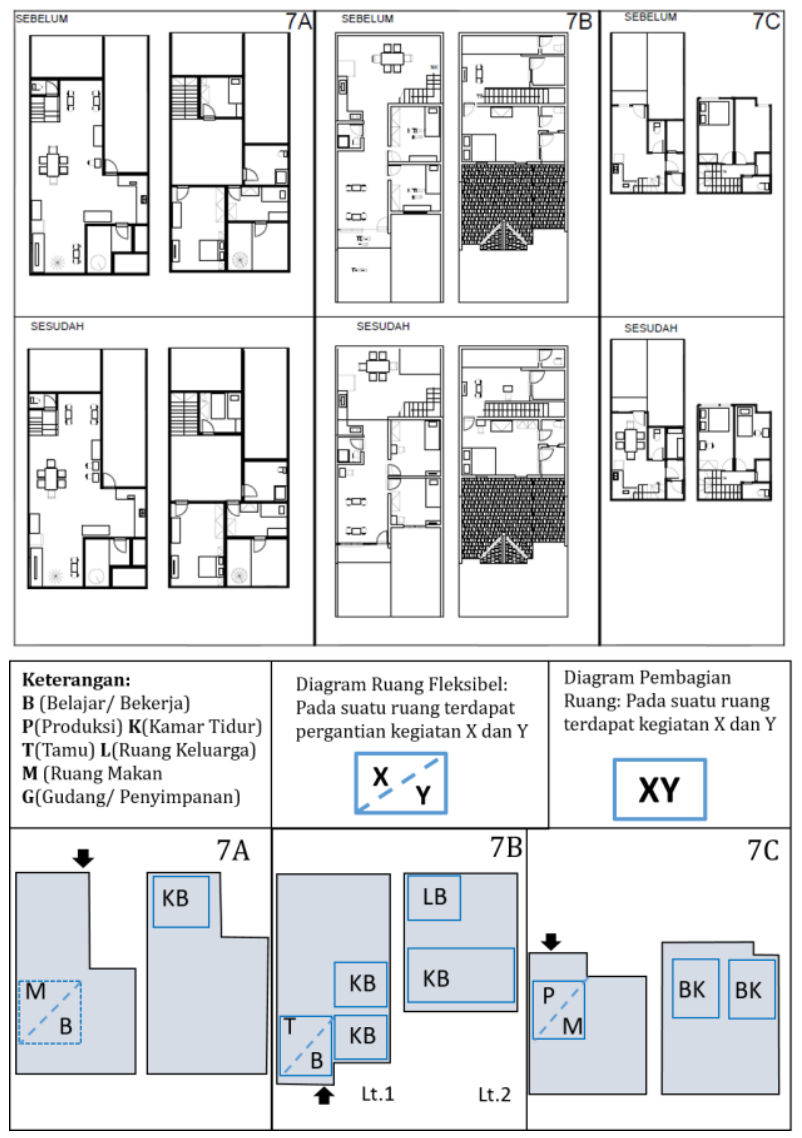

Gambar 6. Proses Analisis pada Klasifikasi Perubahan Penataan berupa Pembagian \& Fleksibel (Penulis, 2020)

Selain ketiga klasifikasi yang paling banyak ditemui pada 20 narasumber tersebut, klasifikasi lainnya memiliki jumlah yang lebih sedikit (Tabel 2). Untuk kategori satu jenis perubahan jumlahnya antara lain: klasifikasi Perluasan dilakukan oleh 2 narasumber; klasifikasi Fleksibel dilakukan oleh 1 narasumber.
Perluasan dilakukan dengan tujuan untuk mewadahi aktivitas bekerja dan belajar agar memperoleh privasi, perluasan dilakukan kearah teras yang melorong serta lantai balkon sehingga terbentuk ruangan tertutup. Ruang fleksibel ditujukan untuk area yang memiliki jangkauan jaringan internet baik, yaitu pada ruang tamu. Sehingga apabila sedang tidak ada tamu, kegiatan belajar dilakukan di ruang tersebut.

Tabel 2. Klasifikasi Perubahan terhadap Perubahan Penataan Hunian

\begin{tabular}{llc}
\hline No. & Klasifikasi Tipe Perubahan & Persentase \\
\hline & Satu Tipe Perubahan & \\
1 & Perluasan & 0,10 \\
2 & Pembagian & 0,15 \\
3 & $\begin{array}{l}\text { Fleksibel } \\
\text { Dua Tipe Perubahan }\end{array}$ & 0,05 \\
& Perluasan +Penukaran & 0,05 \\
5 & Penukaran + Pembagian & 0,30 \\
6 & Perluasan + Flexibel & 0,05 \\
7 & Pembagian + Flexibel & 0,15 \\
& Tiga Tipe Perubahan & \\
8 & Perluasan + Penukaran + & 0,05 \\
& Pembagian & 0,10 \\
\hline & Penukaran + Pembagian + Fleksibel \\
\hline
\end{tabular}

Pada kategori dua jenis perubahan jumlahnya antara lain: klasifikasi Perluasan dan Penukaran dilakukan oleh 1 narasumber; klasifikasi Perluasan dan Fleksibel dilakukan oleh 1 narasumber. Perubahan penukaran ini untuk keperluan pendukung kegiatan produksi, ditambahkan area studio foto dengan memperluas area di taman depan. Sedangkan fleksibel dilakukan untuk menyiasati keterbatasan luas rumah dengan bergantian melakukan kegiatan. Perubahan penukaran bertujuan untuk menyatukan ruang tidur menjadi satu ruang yang sama untuk meminimalisir biaya listrik untuk penghawaan buatan.

Kategori tiga jenis perubahan jumlahnya antara lain: Klasifikasi Perluasan, Penukaran, dan Pembagian dilakukan oleh 1 narasumber; klasifikasi Penukaran, Pembagiann dan Fleksibel dilakukan oleh 2 narasumber. Banyaknya jenis perubahan bertujuan untuk memaksimalkan area agar dapat diperoleh kondisi setiap anggota keluarga dapat melakukan kegiatan bekerja/belajar di ruang terpisah. Sehingga area penyimpanan yang tadinya berada di dalam setiap kamar menjadi dikeluarkan dari kamar. Sementara fleksibilitas dilakukan karena adanya tambahan anggota keluarga baru yang masih bayi, sehingga dengan tidak menambah luas ruangan, maka ruang keluarga menjadi kamar tidur pada saat diperlukan. Fleksibilitas juga dilakukan pada ruang tamu yang apabila sedang tidak digunakan 
menjadi ruang produksi untuk mempersiapkan produk penjualan.

Keterbatasan fisik hunian dan singkatnya waktu perubahan situasi dari situasi normal, menyebabkan setiap keluarga melakukan perubahan penataan yang beragam sesuai dengan kondisi masing-masing. Tipe perubahan "pembagian ruang" paling banyak ditemui karena sebagai akibat dari kebutuhan melakukan kegiatan belajar/bekerja secara privat yang terpisah antar anggota keluarga. Sehingga kegiatan belajar/bekerja tersebut berada di satu ruangan yang sama dengan kegiatan istirahat atau area penyimpanan. Meskipun tidak semua anggota keluarga menerapkan hal ini. Sementara tipe perubahan yang paling jarang ditemui adalah "perluasan ruang". Keluarga yang melakukan perluasan bertujuan untuk memenuhi kebutuhan ruang yang bertambah, hanya jika terdapat area yang memungkinkan dilakukan perluasan tersebut.

Klasifikasi tipe perubahan yang terjadi pada 20 narasumber terbagi menjadi 9 klasifikasi. Hal ini menunjukkan bahwa sangat beragamnya kondisi masing-masing keluarga terhadap perubahan situasi yang sama. Klasifikasi paling banyak ditemukan pada kategori dua perubahan dalam satu hunian, yaitu "Penukaran dan Pembagian" terjadi dalam hunian. Dalam penelitian ini perubahan yang dilakukan dalam satu hunian didapatkan hingga 3 tipe perubahan. Meskipun kategori jumlah perubahan paling sering ditemui adalah sebanyak 2 tipe perubahan.

Setiap keluarga memiliki jumlah anggota yang berbeda, dengan kebutuhan yang beragam. Berhadapan dengan situasi Pandemi Covid-19 yang menuntut untuk melakukan perubahan kegiatan di dalam rumah, setiap anggota keluarga memiliki persepsi masing-masing. Adaptasi telah dilakukan oleh narasumber terhadap situasi yang terjadi secara mendadak dalam waktu singkat. Persepsi kepuasan dengan kecenderungan kearah positif dari 20 narasumber menunjukkan bahwa sebagian besar keluarga dapat melakukan penataan ulang atau adjustment pada huniannya. Kompromi berupa toleransi ialah bagian dari adaptasi coping sebagai bentuk respon terhadap penyelesaian masalah berupa perubahan penataan belum mampu memfasilitasi aspek fungsional pada huniannya.

\section{KESIMPULAN DAN SARAN}

Hasil penelitian menunjukkan bahwa dari 20 narasumber memberikan jawaban persepsi kepuasan kearah positif dan terdapat persepsi kepuasan positif dengan kompromi. Adanya kompromi tersebut mengindikasikan telah terjadi adaptasi coping dalam merespon masalah keterbatasan kebutuhan keruangan. Persepsi kepuasan kearah positif paling tinggi adalah karena faktor akibat kondisi ruangan yang sama seperti sebelumnya atau tidak banyak perubahan. Selain itu terdapat faktor perubahan membuat ruangan terasa lebih luas, serta penataan ruang diubah sesuai kebutuhan. Kompromi paling tinggi ditemukan terhadap kegiatan berbagi fungsi dalam satu ruangan serta kompromi terhadap perubahan jenis kegiatan yang berubah dari tatap muka menjadi dalam jaringan internet. Sedangkan persepsi kepuasan kearah negatif antara lain akibat faktor perubahan ruangan menjadi lebih sempit atau tidak ergonomis.

Hasil penelitian mengenai ragam modifikasi hunian berupa penataan atau adjustment dari tata letak, memperlihatkan bahwa terdapat kombinasi tipe perubahan. Klasifikasi yang paling banyak ditemui ialah Penukaran dan Pembagian. Selain itu ada juga klasifikasi Pembagian saja, dan Pembagian dan Fleksibel. Melihat hasil tersebut, perubahan yang dilakukan penghuni sebagai respon adaptasi terhadap perubahan perilaku menjadi telework, antara lain ialah tipe perubahan penataan hunian dengan pembagian.

Saran yang diberikan untuk penelitian ini adalah mengenai kemungkinan untuk dilakukan kajian lebih jauh dan mendalam mengenai klasifikasi perubahan "pembagian". Tipe perubahan ini paling banyak ditemukan dalan situasi Pandemi Covid-19 yang menuntut untuk melakukan telework. Sehingga perlu diperdalam mengenai material yang digunakan untuk membagi ruang tersebut, pada penataan spasial untuk fungsi yang spesifik. Sehingga hasil penelitian dapat lebih aplikatif dan berguna untuk penyedia hunian.

\section{REFERENSI}

Bell, PA, Fisher, JD \& Loomis, RJ (2006) Environmental Psychology $5^{\text {th }}$ Edition. Philadelphia: W.B. Saunders Company

Budhiekusuma, Noor Partia, S P Hadi, dan Wahyu W Winarno. (2017). Peluang Pemanfaatan Telecommuting dalam Pemerintahan di Indonesia Telecommuting Application Opportunity in Indonesian Government. Jurnal Pekommas, Vol. 2 No. 2, Oktober 2017: 151-160

Grobler, Pieter A., \& Anita De Bruyn. (2011). Flexible Work Practices (FWP) - An effective instrument in the retention of talent: A survey of selected JSE-listed companies. South African Journal of Business Management 42(4)-December 2011

Habraken, N. J and Andres Mignucci. (2014). Conversations with Form: A Workbook for Students of Architecture (pp. 18-24). Routledge

Indriyati, Sri Astuti. (2010). Coping with Physical Environment: The Case Studies of Low-Income Housing in Jakarta. Jurnal Unair, Volume 23, Nomor 4 Hal: 257-268 
Kumar, R. (2005). Research Methodology: A Step-ByStep Guide for Beginners. London: Sage Publication.

Margono, Gaguk. (2014). Pengembangan Instrumen Sikap Terhadap Statistika Menggunakan Skala Diferensial Semantik. Seminar Nasional Psikologi UMS

Maryam, Siti.2017.Strategi Coping: Teori Dan Sumberdayanya. Jurnal Konseling Andi Matappa, Volume 1 Nomor 2 Agustus 2017. Hal 101-107

Panolih, Krishna P. (2020). Rumah, Pusat Hidup Normal Baru Saat Pandemi Covid-19." Kompas.id, 16 May 2020, bebas.kompas.id/baca/riset/2020/05/17/rumahpusat-hidup-normal-baru/.

Mungkasa, Oswar. (2020) Bekerja dari Rumah (Working From Home/WFH): Menuju Tatanan Baru Era Pandemi COVID 19. The Indonesian Journal of Development Planning Volume IV No. 2 - Juni 2020

Munsch, Christin L., Cecilia L. Ridgeway, \& Joan C. Williams. (2014). Pluralistic Ignorance and the Flexibility Bias: Understanding and Mitigating Flextime and Flexplace Bias at Work. Work and Occupations, 41 (Feb 2014):40-62

Potter, Edward E. (2003). Telecommuting: The future of work, corporate culture, and American society. Journal of Labor Research volume 24, pages7384 (2003)

Rahim, Z.A., Hasyim.A.H. (2018). Behavioral Adaptation of Malay Families and Housing Modification of Terrace Houses in Malaysia. Asian Journal of Environment-Behavior Studies, Vol.3, Number 8.

Raviz, Seyed Reza Hosseini, et. al. (2015). Flexible Housing: The Role Of Spatial Organization In Achieving Functional Efficiency. International Journal of Architectural Research, Archnet-IJAR, Volume 9 - Issue 2 - July 2015 - (65-76) Regular Section

Stuart, Gail Wiscarz \& Sundeen. (1991). Pocket Guide to Psychiatric Nursing. The Mosby Company : Toronto. 